\title{
Variability of the Lithic Raw Material in the Upper and Late Palaeolithic sites in Southeastern Poland
}

\section{Dariusz Bobak $^{\mathrm{a}}$ and Marta Połtowicz-Bobak ${ }^{\mathrm{b}}$}

\begin{abstract}
In terms of supply of good quality raw materials for stone tool manufacture, the area of southeastern Poland is rather poor. Considering research conducted so far, there are only few sites that can be the basis for analysis. Nevertheless, certain phenomena seem to be characteristic on sites in southeastern Poland in the later phase of the Upper Palaeolithic and in the Late Palaeolithic. There are usually more than one kind of raw material present. Apart from local erratic flint, imported Świeciechów (grey white-spotted) and 'chocolate' flint dominate. The presence of both Jurassic (areas near Cracow) and Volhynian flints are poorly recorded, whereas resources from the south are almost absent. These imported raw materials indicate the existence of particularly strong relations linking the areas of southeastern Poland with the Sandomierz Upland, and much weaker relationships with the territories of Lesser Poland and Western Ukraine.
\end{abstract}

KEY-WORDS: southeastern Poland, raw materials, Upper Palaeolithic, Late Palaeolithic

The areas of southeastern Poland, understood here more or less as an area within the present-day Podkarpackie Voivodeship, is one area of Poland where there are not known to be outcrops of good-quality flint. In the region of the Podkarpackie region and in the southern part of the Sandomierz Basin, there are a few silicites present. There are erratic flints present e.g., on the Kolbuszowa Plateau, in the central and southern part of the Sandomierz Basin or in the Rzeszów region (near Bratkowice, Raniżów, Wysoka Głogowska and Nienadówka; Mitura et al., 2005: 436). There is also the Bircza flint, whose deposits occur on the Przemyśl Foothills (Łaptaś, et al., 2002, Pelisiak 2016: 195), as well as hornstone of various types e.g., menilite hornstone from the Dukla region, hornstone from Cergowa in the Beskid Niski mountains, siliceous marls found in the Carpathians and in their foothills. Radiolarite also occurs in the Carpathians, especially river valleys (Valde-Nowak 2013: 88; Pelisiak 2016: 195). Therefore, the raw

\footnotetext{
a Fundacja Rzeszowskiego Ośrodka Archeologicznego, ul. Moniuszki ıo, 35-ors Rzeszów; e-mail: d.bobak@ lithics.eu; ORCID: 0000-0002-5216-6630

b Instytut Archeologii Uniwersytet Rzeszowski, ul. Moniuszki Io, 35-oI5 Rzeszów; e-mail: mpoltowicz@ lithics.eu; ORCID: 0000-0003-1973-4971
} 
I2

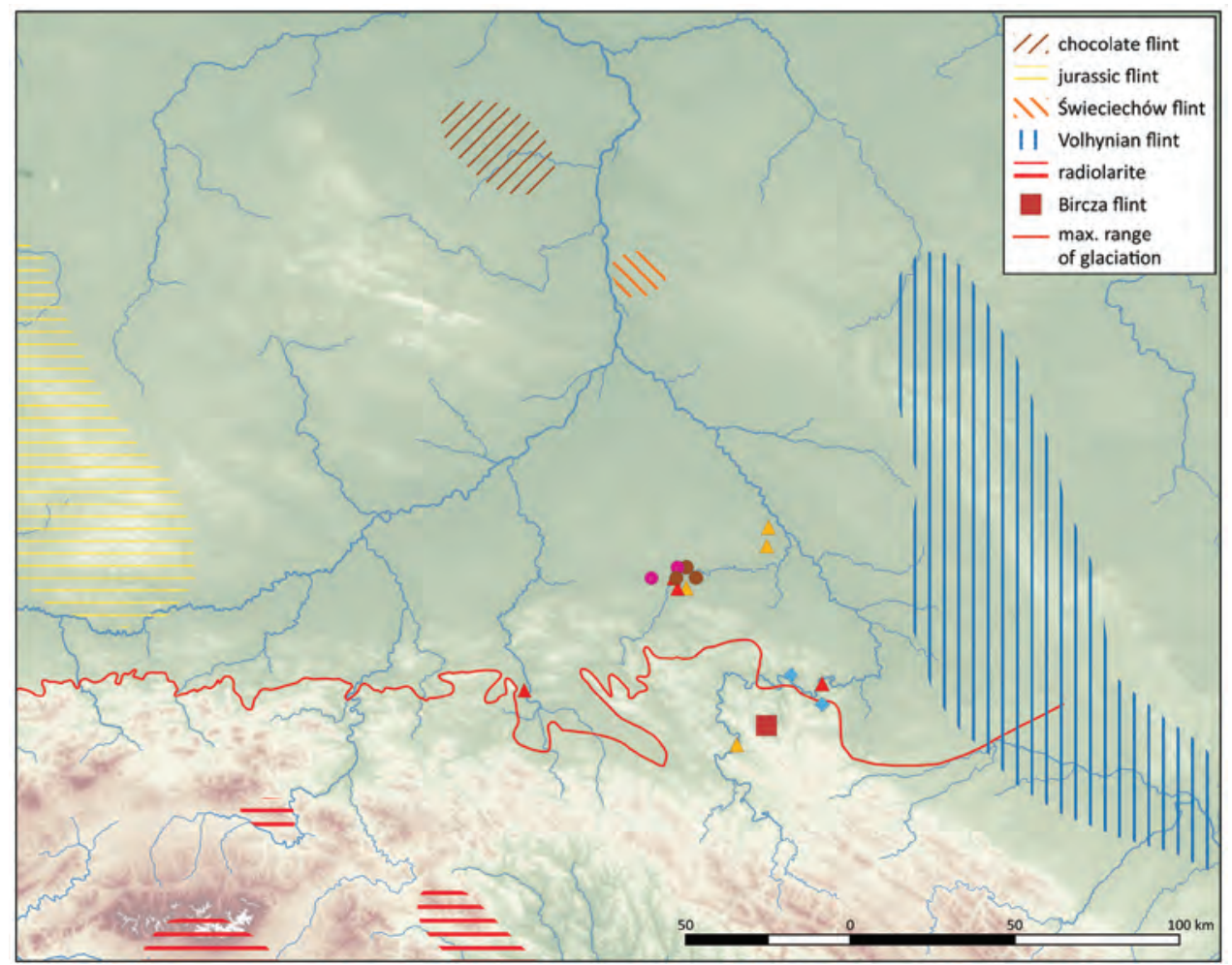

Fig. 1. Outcrops of the main raw materials used on the Palaeolithic sites of southeastern Poland. Computer graphics: D. Bobak.

materials of the discussed areas should be regarded as poor, as well as generally of low quality, and a significant number of them were not used in the Palaeolithic period. That is why groups of hunters and gatherers penetrating area of southeastern Poland used implements produced mainly from good quality imported raw materials (Fig. 1).

Although they are small in quantity, and poor in artefacts, there are Palaeolithic sites in the region covering a broad time frame, from the Middle Palaeolithic (most probably its younger part) to the Swiderian settlement. Based on the analysis of lithic raw material from them, it is possible to notice its variability and make an attempt to record similarities and differences in the use of raw materials and their directions of distribution. Due to the state of the research, which does not allow for more reliable analyses, the sites dated earlier than the younger phases of the Upper Palaeolithic have been omitted in this study. What is more, the remarks applied to the Upper and Late Palaeolithic inventory should be treated as preliminary, reflecting current, but still 


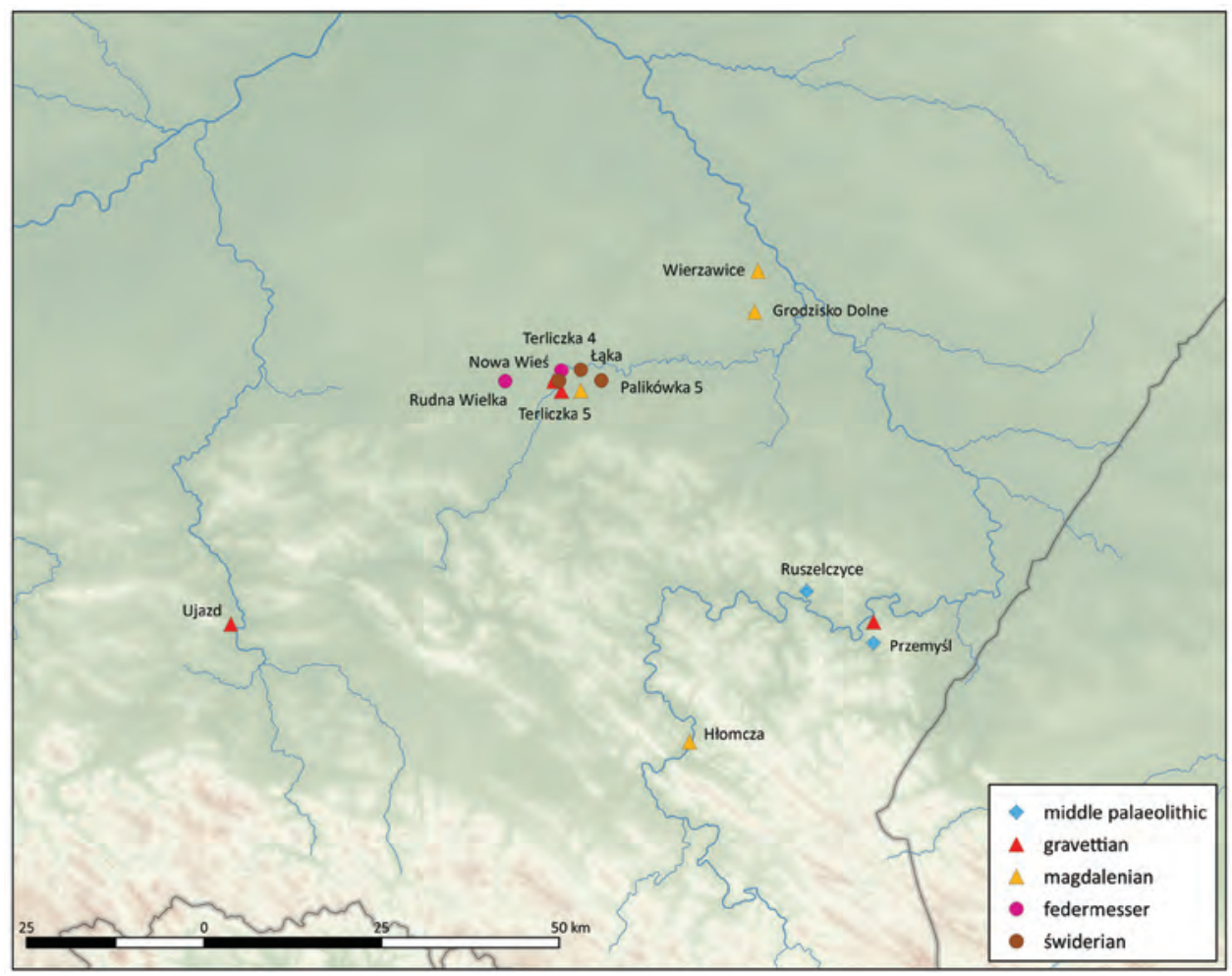

Fig. 2. The most important Upper and Late Palaeolithic sites of southeastern Poland (discussed in the text). Computer graphics: D. Bobak.

insufficient state of our knowledge about the oldest settlements in the southeastern Poland (Fig. 2).

The Upper Palaeolithic settlements are certainly confirmed by Gravettian inventories, which have been discovered so far at very few sites. The most important is the site in Przemyśl, in the former Teich's brick factory on Słowackiego street, which produced an assemblage that can be classified as Gravettian. The material has not been analysed yet. On the basis of the poor data currently available, it can be determined that the artefacts were made, among others, from Świeciechów flint (Osiński 1932; Tomaszewski and Libera 2007), and probably also from Volhynian flint (the burin presented in fig. 3: 4 in the publication of J. Tomaszewski and J. Libera 2007 is rather of Upper Palaeolithic origin). Perhaps other kinds of rocks might have been used there, but with the current lack of published research of the evidence, it is not possible to determine the complete selection of raw material. 
I4 $\mid$ Bobak and Poltowicz-Bobak

Gravettian material was also recorded in Terliczka, Site 4 (Rzeszów district; Gębica and Mitura 2005). According to the researchers, there are two phases that can be distinguished, slightly different in respect of the raw material used there. The authors of the studies presenting the materials from Terliczka have distinguished two Gravettian horizons, perhaps different in their chronology, and also different in their composition: the first one (older?) is made of Volhynian, Dniester, and 'chocolate' flint and radiolarite, whereas the second one contains flint from Bircza, 'chocolate' Carpathian (erratic), , 'chocolate', Świeciechów, erratic flints and radiolarite. However, the studies do not present any information on the percentages of individual raw materials in the inventories.

A large differentiation of the raw materials can be observed on the site Ujazd 6 in the Carpathians (Pawłowska et al., 2003; Valde-Nowak et al., 2005). The poor stone collection is made of Volhynian and Jurassic flint, mainly green radiolarite, hornstone and limnoquartzite. The stones, except of local rocks, come from sources to the east and south. The site could be probably linked with the Epigravettian, however this can be debatable.

The collection from Nowa Wieś (Rzeszów district; Mitura and Pasieka 2005) is also included in the Gravettian or possibly Magdalenian circle. As in the case of the Terliczka 4 site, a very significant variability of the used lithic raw material is observed: artefacts are made of erratic chalk flint, Świeciechów, Volhynian flint, so-called Carpathian 'chocolate' flint, Bircza flint and radiolarite, with the predominance of Carpathian raw materials i.e., radiolarite, Bircza flint, Carpathian 'chocolate' flint, which distinguishes this assemblage from the Late Palaeolithic material.

Large differentiation is also observed in the Magdalenian sites. With regard to the four currently known inventories, only one - the assemblage from Hłomcza was made almost homogeneously of the same raw material i.e., local Bircza flint (Eanczont et al., 2002, 2005). Only two tools are made of Świeciechow flint and one burin spall of Volhynian flint occurs.

Other collections were made of several different types of rocks.

The variety of raw materials used here is noticeable. On the site in Grodzisko Dolne, erratic, 'chocolate', Jurassic and Volhynian flints were noted (Połtowicz 2005: I86, 2006: I5). At the site in Wierzawice, 'chocolate', Świeciechów and erratic flints dominated, but they were accompanied by small amount of Bircza, Jurassic and possibly Volhynian flints (Bobak et al., 20I0: 69). The largest variation in raw materials is observed at the site in Łąka (Połtowicz-Bobak et al., 20I4: 24I). Apart from the dominant flint types ('chocolate' and erratic flints), there were also less numerous Jurassic and Świeciechów flint (here considered together with Gościeradów flint) as well as

\footnotetext{
' So-called Carpathian 'chocolate' flint is found in a secondary deposit in the area of Błażowa, Rzeszów distr., and the areas of the San river.
} 
a few examples of Volhynian flint. In addition, there were also very few radiolarites and local hornstones as well as individual examples of Slovakian limnoquartzite and Dynów marls. It is noteworthy that this is the earliest site in southeastern Poland where a relatively large participation of Jurassic flint (more numerous than Świeciechów flint) was recorded.

In the richest site affiliated to the Federmesser culture from Rudna Wielka (Rzeszów district; Mitura et al., 2005: 423) a quite high variability of raw materials was also reported i.e., next to the most numerous erratic flint from local deposits located several kilometres from the site, the study identified quite a lot of Świeciechów flint and radiolarite, as well as 'chocolate' flint. Probably one artefact might have been made of Jurassic flint. 'Chocolate' and erratic flint is also represented in the part of the inventory described as the Federmesser culture at Terliczka 4 (Gębica et al., 2005).

Changes in the raw material structure are observed in Swiderian sites. It is true that the vast majority of currently known evidence of settlement comes from poor surface finds, but we also have several larger inventories obtained in the course of excavations. The information presented here is based on them.

More than one kind of flint was still used in the Swiderian inventories, but there is visible a decrease in the number of raw materials. With reference to some of the sites, a direction towards the use of certain rock types is noticeable - either 'chocolate' flint or Świeciechów flint, as for instance the large inventory from the site in Terliczka 5 near Rzeszów. Although several raw materials were used ('chocolate', erratic, Świeciechów, Jurassic flints), the most commonly used rock was 'chocolate' flint (Połtowicz-Bobak and Bobak 2007). A very homogeneous raw material of Swiderian inventory was produced by the site in Łąka: apart from the concentration of Magdalenian materials in which a large variability of raw materials is observed, another assemblage (of the Swiderian origin) was identified, in which the inventory was made almost exclusively of 'chocolate' flint (IO2 items out of II2; Bobak and Połtowicz-Bobak 20I5: IO), accompanied by Jurassic flint. What is more, it is at the same time the best recorded site showing the difference in raw materials between Magdalenian and Swiderian inventories, deposited in the same place, and therefore also at the same distance from the outcrops of the rocks.

On the other hand, there are also recorded sites where 'chocolate' flint is known but it is not the most frequently represented kind of raw material. An example of this is a very small assemblage ( 22 or 23 items) from Palikówka (Rzeszów district) where the dominant raw material group is erratic flint, whereas 'chocolate' flint is the second largest group (6 items), also Świeciechów and Jurassic flint and Dynów marl are individually represented by the artefacts (Poradyło et al., 20I4: II). It seems, however, that 'chocolate' flint played a particularly important role in Swiderian assemblages, although unequivocal evidence of its general role is impossible due to the very small number of excavated sites rich in artefacts. 
A workshop where mainly Jurassic flint was processed was discovered in Durdy, near Tarnobrzeg (Talar 1968: 76).

In the Swiderian sites in southeastern Poland, it is worth mentioning that there is a systematic representation of Jurassic and Świeciechów flint, whereas Volhynian flint is not commonly found, even though Swiderian settlement is recorded in Western Ukraine (Bobak et al., 2015, further literature there).

\section{ANALYSIS AND CONCLUSIONS}

There are few Palaeolithic inventories from the south-east of Poland that can be the basis for raw material analyses. However, it is possible to try to outline a more general picture regarding the strategies of obtaining and use of stone raw materials in these areas in different periods of the Upper and Late Palaeolithic (Table 1).

First of all, the variability of the lithic raw materials of inventories is notable regardless of chronology. Manufacturers generally used more than one kind of rock. The Swiderian inventory from Łąka, made almost exclusively from imported 'chocolate' flint, is unique. Noteworthy is the fact that the raw materials used at individual sites come from different regions, sometimes very distant from each other. Gaining rocks from distant places can be explained by the lack of good quality local raw materials. Blade technologies used by the Upper and Late Palaeolithic producers, especially Magdalenian and Swiderian ones, required or at least preferred the use of high quality lithic raw material. Nevertheless, a significant variation of chipped rocks, including those transported from considerable distances, is also observed in inventories affiliated to the Federmesser culture from Rudna Wielka and Terliczka 4, i.e., a taxonomic unit whose flint production was based on simpler methods.

On the other hand, it is striking that local rocks, for instance hornstones, were not generally used in practice. These raw materials, although of average quality, could be flaked, which was confirmed by their use in later periods (e.g., Pelisiak 20I6). Similarly, the so-called Dynów marls were not used, also known as indicated by a Magdalenian core from Łąka (Połtowicz-Bobak et al., 20I4) and a Swiderian tool from Palikówka (Poradyło et al., 20I4: II).

Erratic flint, obtained from local sources, was commonly used. This material was often used throughout the whole period, but as a rule it was only one of several raw materials, and often not the most important category. The flint from Bircza, even though it was already known in the Late Palaeolithic, was not used on a wider scale either. The only exception is the inventory from Hłomcza, made almost entirely of this kind of flint. As for other sites, even if it is recorded, it is only in the form of individual items.

What is more, it is worth considering the directions from which the raw materials were transported and the distance to their sources. The most commonly used rocks 
Table 1. Raw materials on the Upper and Late Palaeolithic sites of the south-east Poland; ch - chocolate flint; chn - chocolate erratic flint; sw - Świeciechów flint; err - erratic flint; vol - volhynian flint; jr - jurassic flint; bi - Bircza flint; ra - radiolarite; oth - other.

\begin{tabular}{|c|c|c|c|c|c|c|c|c|c|c|c|}
\hline \multirow{2}{*}{ Site } & \multirow{2}{*}{ Culture } & \multicolumn{9}{|c|}{ Raw material } & \multirow{2}{*}{ Dominant } \\
\hline & & $\mathrm{ch}$ & chn & $\mathrm{sw}$ & err & vol & $\mathrm{jr}$ & bi & $\mathrm{ra}$ & oth & \\
\hline $\begin{array}{l}\text { Przemyśl, ul. } \\
\text { Słowackiego, } \\
\text { Przemyśl distr. }\end{array}$ & Gravettian & & & + & & + & & & & & $?$ \\
\hline $\begin{array}{l}\text { Terliczka, Site 4, } \\
\text { Rzeszów distr. }\end{array}$ & $\begin{array}{l}\text { Gravettien } \\
\text { (older?) }\end{array}$ & + & & & & + & & & + & & $?$ \\
\hline $\begin{array}{l}\text { Terliczka, Site 4, } \\
\text { Rzeszów distr. }\end{array}$ & $\begin{array}{l}\text { Gravettien } \\
\text { (younger?) }\end{array}$ & + & + & + & + & & & + & + & & $?$ \\
\hline $\begin{array}{l}\text { Nowa Wieś, Site 1, } \\
\text { Rzeszów distr. }\end{array}$ & Gravettien? & & + & + & + & + & & + & + & & ra, bi, chn \\
\hline Ujazd Rzeszów distr. & Epigravettian? & & & & & + & + & & + & + & vol, ra \\
\hline $\begin{array}{l}\text { Hłomcza, 1, Sanok } \\
\text { distr. }\end{array}$ & Magdalenien & & & + & & + & & + & & & bi \\
\hline $\begin{array}{l}\text { Wierzawice, 31, } \\
\text { Leżajsk distr. }\end{array}$ & Magdalenien & + & & + & + & $+?$ & + & $+?$ & & & ch, sw, err \\
\hline $\begin{array}{l}\text { Grodzisko Dolne, } \\
\text { Site 10, Leżajsk distr. }\end{array}$ & Magdalenien & + & & & + & + & + & & & & $?$ \\
\hline $\begin{array}{l}\text { Łąka, 1-16, Rzeszów } \\
\text { distr. }\end{array}$ & Magdalenien & + & & + & + & & + & & + & + & $\mathrm{ch}$, ree \\
\hline $\begin{array}{l}\text { Rudna Wielka, Site } \\
\text { 4, Rzeszów distr. }\end{array}$ & Federmesser & + & & + & + & & + & & + & & err \\
\hline $\begin{array}{l}\text { Terliczka, Site 4, } \\
\text { Rzeszów distr. }\end{array}$ & Federmesser & + & & & + & & & & & & $?$ \\
\hline $\begin{array}{l}\text { Terliczka, Site 5, } \\
\text { Rzeszów distr. } \\
\end{array}$ & Świderien & + & & + & + & & + & & & & $\mathrm{ch}$ \\
\hline $\begin{array}{l}\text { Łąka, 1-16, Rzeszów } \\
\text { distr. }\end{array}$ & Świderien & + & & & + & & & & & & $\mathrm{ch}$ \\
\hline $\begin{array}{l}\text { Palikówka, Site 5, } \\
\text { Rzeszów distr. }\end{array}$ & Świderien & + & & + & + & & + & & & & err \\
\hline
\end{tabular}

came from areas distant from the aforementioned territories about (and most often over) Ioo km away.

The outcrops of 'chocolate' and Świeciechów flints, the most important for the areas discussed here, are about $100 \mathrm{~km}$ to the north of the Podkarpackie region. Similarly, the outcrops of Jurassic flint lie at a distance of more than $100 \mathrm{~km}$ to the west of southeastern Poland. Other materials travelled even greater distances - from sources in Slovakia (perhaps some of the Carpathian radiolarites, limnoquartzite from eastern 
and central Slovakia) and eastern ones (Volhynian flint; Kozłowski 20I3). However, these were used sporadically.

Świeciechów and 'chocolate' flint, found at Gravettian sites came from regions from which there is no record of settlement of that time. In the assemblage from Terliczka 4, eastern imports (Volhynian and Dniester flints) and Carpathian radiolarite were recorded. These rocks determine a route of migration along the west-east axis and possibly towards the south, which tends to agree with our knowledge about the migration of Gravettian communities at the beginnings of the Last Glacial Maximum (LGM). Volhynian flint from east and limnoquartzite from the south is known from Ujazd as well.

Very numerous imports of 'chocolate' and Świeciechów flints at Magdalenian sites are associated with the presence of rich sites (including workshops) near Sandomierz (Sandomierz district; Połtowicz-Bobak 2013, further literature there). Individual radiolarites, if they do not come from secondary deposits, may be linked with the Carpathian outcrops the exploitation of which is confirmed by the Magdalenian site (a workshop) in Sromowce Wyżne - Kąty (Nowy Targ district; Valde-Nowak 199I). There are also very few cases of Jurassic flint near Cracow. All of the mentioned rocks come from the areas where Magdalenian settlement is recorded. On the basis of raw material distribution, it is possible to infer that the areas of southeastern Poland were most strongly connected with the northern edges of the Sandomierz Basin, where a distinct settlement centre has been recorded. The nature of these links remains to be clarified, although it may be assumed that these areas belonged to one territory exploited by communities affiliated to this cultural unit (Połtowicz-Bobak 20I3, further literature there).

However, it is worth mentioning that there are also raw materials coming from outside the currently known borders of the Magdalenian, i.e., a few items of Volhynian flint and Slovak limnoquartzite. They can indicate the existence (perhaps indirect) of relations between communities supposedly belonging to different taxonomic units.

The directions for the distribution of lithic raw materials found at Swiderian sites clearly indicate the dominance of the connections between southeastern Poland and the areas located further to the north, on the edges of the Świętokrzyskie (Holy Cross) Mountains, where the outcrops of 'chocolate' and Świeciechów flints are located. These two kinds of flint, especially the 'chocolate' type, are the basic raw material used at Swiderian sites. The third basic raw material used by Swiderian producers was local erratic flint, but of good quality. On the other hand, Jurassic flint, coming from the areas of the Cracow-Częstochowa Upland is represented marginally. The exception here is a small workshop in Durdy (Tarnobrzeg district) in the Sandomierz Basin, where mainly cores were produced from this raw material (Talar 1967). This suggests that the Swiderian communities, occupying the areas of southeastern Poland, mainly exploited the areas located on the eastern side of the Vistula. What is more, the participation of 
eastern raw materials, i.e., Volhynian flint, whose outcrops are located in areas covered by the Swiderian settlement, is also very small.

It is interesting that, regardless of the chronology and cultural affiliation, the lithic raw materials represented at the sites constitute a repetitive set of types that is dominated by three of them: erratic, Swieciechów and 'chocolate' flint. Only erratic flint appears locally. The deposits of the other two not only lie beyond reach of a one-day journey, but also (in the case of sites older than Magdalenian) they are in areas outside the lands penetrated by the population of particular cultures. Therefore, it is possible to exclude gaining these resources during, for example, systematic hunting expeditions. The expeditions looking for raw materials had to be undertaken intentionally outside the areas exploited economically (hunting) by the manufacturers. In the case of the Magdalenian culture, the distribution of raw materials clearly shows the links between the southeastern Poland and the northern part of the Sandomierz Basin (the northern extent of the Magdalenian in Poland), and together with the poor supply of raw materials from the territory near Cracow suggesting little contact between these two areas (Połtowicz-Bobak 2013). The thesis about closer relations between the areas of the Podkarpacie region and the edges of the Sandomierz Basin is reinforced by observation of the settlement structure.

The same set (indicating strong links with the northern areas) of 'chocolate' and Swieciechów flints, playing the main role in the raw material composition alongside the local flint, also dominates at Swiderian sites. Components of such a set can be well explained by both mobile lifestyle and connections between the areas discussed here and the areas of the Sandomierz Upland and Lowlands. Furthermore, it is worth mentioning the constant, though usually poorly evidenced, occurrence of imported raw materials, most often flints coming from areas lying to the east - Volhynian or Dniester flint, whose presence is repeated on most sites from different periods. Exceptions, however, include imports from the south, i.e., radiolarites and a single example of limnoquartzite.

On the basis of the analysis of raw materials of inventories from southeast Poland, several phenomena can be observed. First of all, the widespread use is noticeable of two kinds of imported raw material, brought from considerable distances, together with a weak interest in local raw materials (other than erratic flint), and lack of greater interest in eastern resources (Volhynian flint) and equally good-quality flint from the Cracow region. However, eastern and western raw materials are still present in the Palaeolithic sites of today's Podkarpackie Voivodeship as opposed to the southern raw materials, which are very poorly documented.

It seems that the areas of southeastern Poland are more closely linked with areas further to the east than those located on the southern side of the Carpathians. What is more, the quantities of raw materials coming from Lesser Poland suggest poorly developed contacts with this region. At the same time, it is worth emphasizing the 
constant and probably systematic exploitation of flint sources deposited in the north. Taking everything into account, it is possible to develop the thesis that an important element in the formation of the cultural image was the Vistula river, which in its upper course could have comprised a significant boundary between the territories exploited by particular late Palaeolithic communities, at least ones older than Swiderian. It seems that this phenomenon should be explained by cultural determinants rather than natural ones, although its nature is still unknown to us.

Research on the Palaeolithic in southeastern Poland still does not allow us to answer many questions regarding the earliest periods of the history of this region. It is, therefore, to be hoped that that further work, especially new discoveries, will allow a deeper knowledge of the issues and provide more reliable answers to the questions asked by the researchers.

\section{REFERENCES}

Bobak, D., Łanczont, M., Nowak, A., Połtowicz-Bobak, M. and Tokarczyk, S. 20Io. Wierzawice st. 3I nowy ślad osadnictwa magdaleńskiego w Polsce południowo-wschodniej. Materiaty i Sprawozdania Rzeszowskiego Ośrodka Archeologicznego 31: 63-78.

Bobak, D. and Połtowicz-Bobak, M. 20I5. Materiały świderskie ze stanowiska Łąka I-I6 (pow. rzeszowski) na tle osadnictwa w Polsce południowo-wschodniej. Materiaty i Sprawozdania Rzeszowskiego Ośrodka Archeologicznego 34: 9-16.

Gębica, P. and Mitura, P. 2005. Wstępne wyniki badań geomorfologiczno-archeologicznych przeprowadzonych na stanowisku nr 4 w Terliczce k. Rzeszowa. In M. Kuraś (ed.), Archeologia Kotliny Sandomierskiej 4, 19-38. Stalowa Wola, Rocznik Muzeum Regionalnego w Stalowej Woli.

Kozłowski, J.K. 20I3. Raw materials procurement on the Late Gravettian of the Carpathian Basin. In Z. Mester (ed.), The lithic raw material sources and interregional human contact in the northen carpathian regions, 63-85. Kraków-Budapest.

Łanczont, M., Madeyska, T., Muzyczuk, A. and Valde-Nowak, P. 2002. Hłomcza - stanowisko kultury magdaleńskiej w Karpatach polskich. In J. Gancarski (ed.), Starsza i środkowa epoka kamienia w Karpatach polskich, I47-I87. Krosno.

Łaptaś, A., Mitura, P. Muzyczuk, A., Olszewska, B., Paszkowski, M. and Valde-Nowak, P. 2002. Krzemień z Birczy. Geologia i wykorzystywanie w pradziejach. In J. Gancarski (ed.), Starsza i środkowa epoka kamienia w Karpatach polskich, 315-337. Krosno.

Mitura, P. and Pasieka, A. 2005. Materiały krzemienne ze stanowiska I w Nowej Wsi, gm. Trzebownisko, woj. podkarpackie. Materiaty i Sprawozdania Rzeszowskiego Ośrodka Archeologicznego 26: 5-24.

Mitura, P., Pasieka, A. and Słowik, K. 2005. Late Palaeolithic materials from site 4 in Rudna Wielka, Świlcza commune, podkarpackie voivodship. Sprawozdania Archeologiczne 57: 42I-44I.

Osiński, K. 1932. Najstarsze ślady człowieka dyluwialnego w Przemyślu. Ziemia 19: 278.

Pawłowska, M., Petrykowski, S. and Valde-Nowak, P. 2003. Verification surface studies of the Upper Palaeolithic site at Ujazd county of Jasło (Poland). Praehistoria 4-5: 153-I64.

Pelisiak, A. 20I6. Krzemienie narzutowe w społecznościach młodszej epoki kamienia i wczesnego okresu epoki brązu wschodniej części Karpat polskich i Podkarpacia. In W. Borkowski, B. Sałacińska and S. Sałaciński (eds), Krzemień narzutowy w pradziejach, I93-2I2. Warszawa. Studia nad gospodarką surowcami krzemiennymi w pradziejach 8 . 
Variability of the Lithic Raw Material in the Upper and Late Palaeolithic sites in Southeastern Poland $\mid 21$

Połtowicz, M. 2005. Wykorzystanie i dystrybucja surowców kamiennych w paleolicie Polski południowowschodniej. In M. Kuraś (ed.), Archeologia Kotliny Sandomierskiej Rocznik Muzeum Regionalnego $w$ Stalowej Woli 4, I83-193. Stalowa Wola.

Połtowicz, M. 2006. The eastern borders of the Magdalenian culture range. Analecta Archaeologica Ressoviensia I: II-28.

Połtowicz-Bobak, M. 2013. Wschodnia prowincja magdalenienu. Rzeszów.

Połtowicz-Bobak, M. and Bobak, D. 2007. Materiaty krzemienne ze stanowiska Terliczka 5, woj. Rzeszów. Unpublished conservation study. Rzeszów.

Połtowicz-Bobak, M., Bobak, D. and Gębica, P. 20I4. Nowy ślad osadnictwa magdaleńskiego w Polsce południowo-wschodniej. Stanowisko Łąka II-I6 w powiecie rzeszowskim. Materiaty i Sprawozdania Rzeszowskiego Ośrodka Archeologicznego 35: 237-248.

Poradyło, W., Bobak, D., Pasterkiewicz, W. and Połtowicz-Bobak, M. 20I4. Wielokulturowe stanowisko nr 5 w Palikówce. Rzeszów. Via Archeologica Ressoviensis.

Talar, A. 1967. Schyłkowopaleolityczna pracownia krzemieniarska w Durdach pow. Tarnobrzeg. Materiaty Archeologiczne 8: 75-83.

Talar, A. 1968. Paleolit schyłkowy w południowo-wschodniej Polsce. Rocznik Muzeów Województwa Rzeszowskiego I: 5-31.

Tomaszewski, A.J. and Libera, J. 2007. Paleolityczne materiały z Przemyśla w zbiorach Państwowego Muzeum Archeologicznego (dzieje kolekcji). Rocznik Przemyski 43 (2): 3-IO.

Valde-Nowak, P. 199I. Studies in Pleistocene settlement in the Polish Carpathians. Antiquity 65: 593-606.

Valde-Nowak, P. Łanczont, M. and Pawłowska, M. 2005. The Upper Palaeolithic Site at Ujazd (Polish Carpatians). Acta Archaeologica Carpathica 40: 5-26.

Valde-Nowak, P. 20I3. The North-Carpathians province of silica rock during Stone Age. In Z. Mester (ed.), The lithic raw material sources and interregional human contacts in the northern Carpathian regions, 87-98. Kraków. 
